\title{
Pengaruh Variabel Makroekonomi Terhadap Jumlah Penghimpunan Zakat di Indonesia
}

\author{
Sheema Haseena Armina \\ Faculty of Economic and Business, Magister of Islamic Economics Science \\ Universitas Airlangga, Surabaya \\ Email: sheema.haseena.armina-2018@pasca.unair.ac.id
}

\begin{abstract}
Abstrak: Tujuan Penelitian ini menganalisis tentang pengaruh Indeks Produksi Industri, kurs dollar, inflasi dan BI 7-Day Rate Rate terhadap jumlah penghimpunan zakat dari periode Januari 2015 sampai Desember 2018 untuk mengidentifikasi potensi jumlah zakat yang terhimpun guna menjadi pendukung pengentasan kemiskinan di Indonesia. Metodologi/Pendekatan: Penelitian ini menggunakan pendekatan kuantitatif dengan teknik analisis data Vector Error Correction Model (VECM) dengan data sampel time series dari Januari 2015 sampai Desember 2018. Temuan: Hasil menunjukkan bahwa kausalitas jangka pendek, didapatkan adanya hubungan kausalitas jangka panjang dan pendek zakat sebagai variabel dependen dengan inflasi dan kurs dollar. Namun, tidak ada hubungan kausalitas jangka pendek antara BI 7-DRR dan IPI terhadap jumlah zakat sedangkan hubungan kausalitas jangka panjang, semua variabel independen memiliki hubungan signifikan terhadap variabel dependen yaitu zakat. Implikasi: Integrasi lembaga filantropi Islam berpotensi menyalurkan bantuan dan dukungan untuk mengentaskan kemiskinan. Penelitian ini menambahkan variabel IPI untuk menginterpretasikan variabel PDB dalam melihat pengaruhnya terhadap zakat.
\end{abstract}

Kata kunci: Indeks Produk Industri, Kurs Dollar, Inflasi, BI 7 Day Repo Rate, Zakat

Abstract: Purpose this study analyzes the effect of the industrial production index, the dollar exchange rate, inflation and the BI 7DRR on the amount of zakat collection from January 2015 to December 2018to identify the potential of zakat to support alleviation in Indonesia. Methodology/Approach: this study uses a quantitative approach with a Vector Error Correction Model (VECM) data analysis technique with time series data from Januari 2015 t0 December 2018. Findings: The results show that in short term causality, there is an effect between long-term and short-term between zakat as the dependent variable with inflation and the dollar exchange rate. However, there is no short-term causality effect between BI 7DRR and IPI to the amount of zakat while the long-term causality effect, all independent variables have a significant effect to the dependent variable namely zakat. Implications: The integration of Islamic philanthropic institutions has the potential to channel aid and support to alleviate poverty. This study adds the IPI variable to interpret the GDP variable in analyzing its effect on zakat.

Keywords: Industrial Production Index, Dollar Exchange Rate, Inflation, BI 7-DRR, Zakat 


\section{PENDAHULUAN}

Potensi zakat yang menjadi salah satu harapan untuk mendorong pertumbuhan ekonomi dan kesejahteraan masyarakat. Instrumen ini wajib dikeluarkan oleh Muslim dalam upaya mengurangi tingkat kemiskinan berdasarkan nilai spiritual. Meskipun hal ini sering dibahas oleh para ahli dan peneliti, tidak menutup kemungkinan bahwa jumlah zakat yang terhimpun mengalami fluktuasi naik turun. Badan Zakat Nasional (BAZNAS) menjadi sebuah wadah yang digunakan untung menampung zakat para Muslim untuk dapat disalurkan kepada orang yang berhak menerimanya sesuai dengan syari'ah. Pasalnya, penting untuk dianalisa bahwa kemungkinan adanya pengaruh makroekonomi dalam hal penghimpunan zakat menjadi salah satu kesadaran masyarakat untuk mewaspadai dan tetap menunaikan kewajiban dalam membayar zakat meskipun potensinya masih jauh untuk menyelesaikan masalah kemiskinan (Andriyanto, 2011).

Catatan Baznas pada tahun 2018 bahwa ada sekitar 38.500 muzakki (orang yang berzakat) dengan jumlah zakat yang terhimpun 206.3 miliyar dimana zakat tersebut disalurkan sekitar 197 milyar kepada 636.900 mustahiq (orang yang berhak menerima zakat) di seluruh Indonesia (baznas.go.id). Ketimpangan pendapatan antara yang kaya dengan miskin menjadi salah satu masalah yang kompleks di negara berkembang seperti Indonesia. Data di atas menyimpulkan bahwa masih banyak muzaki yang tidak menyalurkan zakatnya melalui BAZNAS sehingga jumlah yang seharusnya dapat dihimpun dengan jumlah lebih, masih jauh di bawah perkiraan.

Menurut (Cokrohadisumarto, 2019) bahwa pembayaran zakat perlu dibentuk dengan baik dengan peningkatan pemahaman zakat dan memperkuat kredibilitas lembaga pengelola zakat serta memperkuat aliran informasi dari lembaga pengelola zakat kepada masyarakat. Keberadaan pengelola zakat Baznas sangat penting karena bukan hanya sebagai bentuk ucapan pemenuhan rukun Islam namun lebih luas kepada bidang sosial, ekonomi dan kesejahteraan masyarakat.

Gambar 1. Perbandingan Pengumpulan ZIS 2016-2017

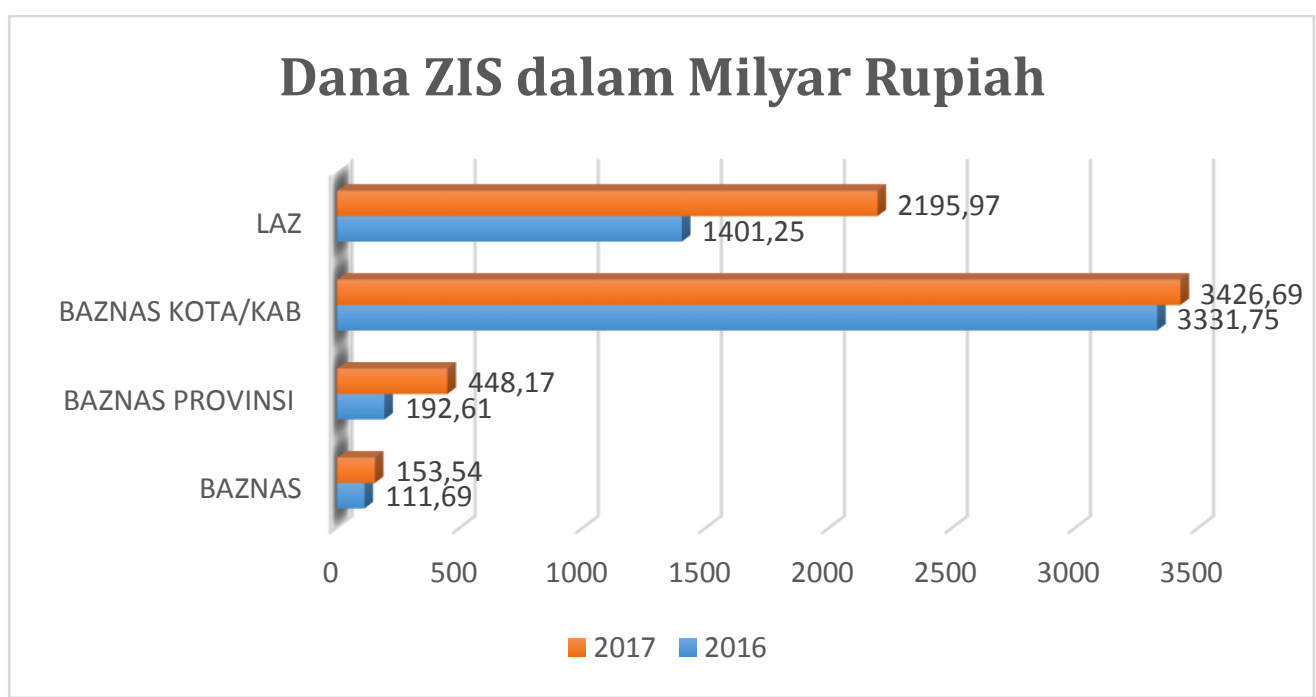

Sumber: Statistik Zakat Nasional 2017 (data diolah) 
Berdasarkan grafik di atas dapat disebutkan bahwa perbandingan dari tahun 20162017 berpotensi untuk tumbuh dan meningkat, dilihat dari pertambahan jumlah yang positif di tahun 2017. Namun berkenaan dengan hal tersebut, untuk membantu dan mendorong pertumbuhan ekonomi Indonesia, pemerintah perlu mengidentifikasi sektor-sektor potensial sebagai penggerak dalam memajukan pembangunan daerah (Anggara, 2017). Perubahan ataupun pertumbuhan dari setiap tahunnya memungkinkan adanya beberapa variabel makroekonomi yaitu inflasi, BI 7-DRR, kurs dollar terhadap rupiah dan variabel lainnya, disinyalir dapat dijadikan penentu dalam menganalisis masalah ekonomi di Indonesia.

Nilai tukar yang diinterpretasikan dari kurs dollar sebagai harga dari mata uang yang digunakan untuk melakukan transaksi perdagangan antar negara satu dengan negara lainnya, ditentukan dari jumlah permintaan dan penawaran (Mankiw, 2007). Sedangkan menurun atau meningkatnya nilai tukar kurs dollar yang ditetapkan oleh Bank sentral juga menyesuaikan nilai tukar mata uang yang ada di pasar sehingga juga berdampak pada praktek seseorang khususnya dalam menunaikan kewajiban berzakat (Afendi, 2018).

Menurut (Rio, 2016) perihal inflasi bahwasanya setiap naiknya satu persen inflasi maka akan berpengaruh terhadap tingkat konsumsi seseorang yang mana pendapatan lebih banyak dihabiskan untuk mengkonsumsi dan memenuhi kebutuhan sehingga mengorbankan zakat. Hal lain juga bisa terjadi salah satunya adalah orang yang awalnya adalah muzakki akhirnya tidak mampu membayar zakat dan berakhir menjadi orang yang berhak menerima zakat.

Sedangkan BI 7-DRR menjadi hal yang penting dalam pembahasan ini karena dalam penelitian (Lidya dan Maryati, 2015) menyatakan bahwa BI 7-DRR ini berkenaan dengan investasi dan pinjaman uang kepada pihak bank yang artinya semakin rendah tingkat bunga yang diterima maka semakin banyak orang yang akan meminjam uang ke bank untuk keperluan pemenuhan kebutuhan ataupun bisnis yang dijalankan oleh masyarakat.

Lain halnya dengan Indeks Produksi Industri (IPI) menjadi salah satu indikator yang menggambarkan produksi sektor industri manufaktur, pertambangan, dan barang pabrikan lainnya seperti migas dan listrik (www.bps.go.id). Menurut (Skintzi, 2018) bahwa indeks produksi industri meningkat pada tahun 2017 untuk tahun ketiga secara berturut-turut yaitu dengan peningkatan sebesar 4,6\% dibandingkan dengan tahun 2016.

Peningkatan indikator ini kerap kali mengintepretasikan PDB dalam bentuk bulanan, triwulanan ataupun tahunan yang mencakup data tentang hal-hal di atas namun analisis yang mencakup IPI berkaitan dengan zakat masih sangat minim. Hal ini penting karena PDB merupakan salah satu komponen pendapatan nasional yang menyediakan informasi tentang ekonomi suatu negara (Saadillah, 2019).

Pembahasan ini diharapkan dapat menganalisis secara lebih lanjut perihal pentingnya instrumen Islam ini untuk menjadi salah satu acuan dalam upaya pertumbuhan ekonomi. Problematika yang disampaikan sebelumnya tidak terlepas kaitannya dengan konsumsi masyarakat. Penelitian sebelumnya telah banyak membahas tentang penghimpunan zakat dan kaitannya dengan variabel makroekonomi namun masih jarang ditemukan pembahasan mengenai IPI dan pengarunya pada penghimpunan zakat. Inflasi, BI 7DRR dan kurs dollar menjadi variabel kontrol dalam pengaruhnya terhadap zakat namun penulis ingin menganalisa terkait pengaruh IPI sebagai variabel baru yang masih jarang ditemukan pengaruh analisisnya terhadap pengumpulan jumlah zakat.

Berdasarkan hal yang telah dikemukakan di atas, penelitian ini bukan hanya bertujuan untuk mengetahui pengaruh kurs dollar, inflasi dan BI 7DRR terhadap penghimpunan zakat 
di Indonesia namun secara tidak langsung menjelaskan bahwa jumlah zakat yang terkumpul berpotensi untuk mengurangi kemiskinan dan berfungsi secara optimal dalam mensejahterakan masyarakat secara materi maupun spiritual.

\section{KAJIAN TEORI}

Penghimpunan Zakat. Menurut (Cokrohadisumarto, 2019); (Kasri, 2013) zakat merupakan instrumen sosial dalam pertumbuhan ekonomi dimana hal ini masuk dalam rukum Islam yang ketiga bahwa menunaikan zakat adalah wajib bagi orang-orang Muslim yang mampu dengan tujuan untuk kesejahteraan umat. Zakat juga sebagai salah satu dari kesekian ajaran sosial Islam yang berorientasi pada kemaslahatan kemanusiaan (Huda, 2012). Berdasarkan Surat At Taubah (9): 103 tentang kewajiban berzakat;

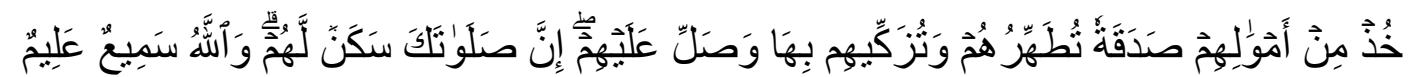

"Ambillah zakat dari sebagian harta mereka, dengan zakat itu kamu membersihkan dan mensucikan mereka dan mendoalah untuk mereka. Sesungguhnya doa kamu itu (menjadi) ketenteraman jiwa bagi mereka. Dan Allah Maha Mendengar lagi Maha Mengetahui.",

Peranan penting yang dimainkan oleh zakat mencakup aspek agama, ekonomi, politik dan sosial (Omar, 2016). Harta yang hendak dizakatkan harus sepenuhnya milik orang Islam yang merdeka tanpa hasil campur tangan orang lain dimana masyarakat yang memiliki harta yang berlebih dari penghasilannya digunakan untuk kepentingan pembangunan masyarakat Islam dan mengentaskan masalah kemiskinan (Obaidullah, 2016)

Sedangkan menurut (Rahmat dan Nurzaman, 2019) bahwa distribusi zakat menjadi masalah yang kompleks, pasalnya institusi filantropi dan adminisator zakat perlu meningkatkan kegiatannya secara efektif dalam menggalakkan semangat keislaman dalam berdakwah salah satunya untuk turut berzakat melalui lembaga tersebut. Hal ini menyiratkan bahwa keuangan Islam sangat berkaitan dengan program pengentasan kemiskinan sebagai tanggungjawab sosial yang mendasar untuk mencapai kesejahteraan.

Data penghimpunan zakat yang didapatkan dari Baznas Pusat menjadi acuan awal dalam menganalisis perihal pengaruh beberapa variabel makroekonomi yang mana mempengaruhi ataupun tidak mempengaruhi penghimpunan zakat itu sendiri sehingga secara informatif bahwa penelitian ini bisa memberikan pandangan bagi masyarakat dan akademisi untuk penelitian selanjutnya.

Pengaruh Variabel Makroekonomi terhadap Jumlah Zakat. Secara bertahap variabel makroekonomi dikaitkan dengan berbagai indikator atau variabel ekonomi lainnya. Kaitan ini menjadi sebuah kemungkinan turun atau meningkat daya beli masyarakat dan prospek pertumbuhan ekonomi. Menurut pandangan Islam dari (Chapra, 2018b) menyatakan bahwa bahwa tingkat suku bunga merupakan harga yang menghubungkan masa kini dan masa depan dimana cenderung menjadi harga yang menyesatkan karena mencerminkan diskriminasi harga dengan memihak lebih kepada orang kaya yang pantas untuk mendapatkan pinjaman karena diasumsikan bahwa lebih besar produktivitasnya akan menanggung beban yang paling kecil, dengan rating kreditnya yang lebih tinggi. Didukung oleh penelitian (Sulistiana, 2017) yang menyatakan bahwa tingkat BI 7DRR merupakan 
variabel yang cukup dominan dalam memberikan kontribusi fluktuasi yang berhubungan dengan inflasi yang dapat dijadikan acuan oleh otoritas moneter dan pengambil kebijakan sebagai instrumen untuk menstabilkan inflasi (Saikh, 2015).

(Chapra, 2018a) juga menyatakan bahwa inflasi cenderung kepada redistribusi pendapatan kepada golongan atas sehingga menimbulkan ketidakseimbangan terhadap sasaran keadilan sosioekonomi. Bukan hanya itu, dampak lainnya juga berkaitan dengan keberlanjutan pembangunan khususnya pada bidang ekonomi. Diperkuat dengan hasil penelitian dari (Saadillah, 2019) bahwa variabel inflasi dapat menyebabkan penurunan kualitas hidup yang berakibat lebih kepada konsumsi masyarakat. Inflasi yang tinggi menjadikan daya beli masyarakat menurun khususnya dalam memenuhi kebutuhan pokok dan akibatnya berefek kepada kewajiban menunaikan zakat karena bergantung pada pendapatan masyarakat itu sendiri sehingga pada akhirnya mengorbankan pembayaran zakat.

Sedangkan nilai tukar terhadap dollar ini menjadi bagian dari kebijakan moneter yang mana bertujuan untuk menjaga kestabilan nilai rupiah. Kestabilan ini terbagi menjadi dua dimensi yaitu kestabilan nilai rupiah yang berkaitan dengan harga-harga barang dan jasa dilihat dari perkembangan laju inflasi. (Afendi, 2018) menyatakan bahwa nilai tukar terhadap dollar telah diterapkan di Indonesia sehingga berdampak kepada perkembangan ekonomi nasional dari sektor moneter ataupun sektor riil. Berkenaan dengan variabel makroekonomi, masalah dari penerima zakat masih sulit untuk diidentifikasi datanya dalam kisaran jumlah dan kategori oleh lembaga zakat. Namun, dana yang disalurkan masyarakat untuk berzakat masih terus mengalir meskipun aliran zakat tidak sepenuhnya masuk ke dalam lembaga zakat yang berperan penting dalam membantu menyalurkan dananya. Menurut (Ahmed et al., 2017) bahwa studi zakat empiris di daerah barat daya Nigeria menganalisis tentang kontribusi zakat dalam membaharui kesejahteraan orang miskin dan penerima zakat dan saran dalam penetapan kriteria kemiskinan lokal. Hal ini mengingat bahwa ukuran kemiskinan di pedesaan dan perkotaan tidak memiliki kriteria yang spesifik sehingga orang miskin mungkin tidak tahu bahwa mereka memenuhi syarat untuk mendapatkan zakat (Sloane, 2019).

Hasil (Fitriah et al., 2015) dalam penelitiannya menyatakan bahwa inflasi berpengaruh negatif dan signifikan terhadap penerimaan zakat yang artinya adalah setiap kenaikan tingkat inflasi akan membuat penerimaan ZIS di Baznas mengalami penurunan karena inflasi ini berkaitan dengan harga barang-barang secara umum yang tentunya berkaitan dengan harga beras dan emas sebagai penentu penetapan nisab zakat. Hal ini sesuai dengan teori yang menyatakan bahwa kenaikan tingkat inflasi yang bukan berarti pendapatan juga ikut meningkat, hal ini mempengaruhi kemampuan muzakki dalam mencapai batas nisabnya sehingga kemungkinan seseorang itu tidak lagi menjadi muzakki atau bisa menjadi orang yang berhak mendapatkan zakat.

Sedangkan penelitian dari (Saadillah, 2019) menjelaskan bahwa pengaruh inflasi terhadap jumlah penghimpunan zakat dalam jangka pendek negatif dan tidak signifikan sedangkan dalam jarak panjang memiliki pengaruh negatif yang signifikan sehingga hipotesis yang diterima bahwa ada pengaruh negatif pada inflasi terhadap jumlah zakat periode 2011-2017. Hal ini sesuai dengan teori yang dikemukakan oleh (Mankiw, 2007) bahwa tingkat kenaikan inflasi akan meningkatkan harga barang dan akhirnya nilai mata uang juga akan semakin menurun yang berdampak pada pengurangan daya beli masyarakat. Sedangkan pengaruh BI 7DRR dalam jangka panjang memiliki pengaruh negatif dan tidak 
berpengaruh signifikan terhadap jumlah zakat sehingga menunjukkan bahwa setiap kenaikan BI 7DRR sebesar satu persen maka akan berdampak pada penurunan jumlah zakat yang akan diterima oleh Baznas Pusat untuk disalurkan kepada masyarakat yang membutuhkan.

Sedangkan pada hasil penelitian (Rio, 2016) bahwa kurs dollar berpengaruh tidak signifikan terhadap jumlah zakat pada lembaga Amil Zakat di Dompet Dhuafa dari periode 1997-2013. Hasil ini tidak sejalan dengan penelitian (Ahmad, 2011) bahwa kurs dollar memiliki pengaruh yang signifikan terhadap penghimpunan dana zakat bahwasanya meningkatnya kurs dollar ini memiliki dampak buruk walaupun memiliki dampak baik juga. Jika dilihat kepada dampak baiknya bahwa meningkatnya nilai tukar rupiah terhadap dollar dapat menguntungkan masyarakat yang penghasilannya dalam bentuk dollar seperti para eksportir karena hal ini menjadi sebuah berkah dikarenakan penghasilan mereka jauh lebih banyak dari sebelumnya kemudian apabila dikaitkan dengan zakat maka akan berdampak pada meningkatnya jumlah zakat yang mereka keluarkan karena perhitungan pada pendapatan mereka yang juga meningkat.

Indikator suku bunga menurut (Sulistiana, 2017) memiliki pengaruh yang signifikan karena keputusan seseorang untuk membelanjakan atau menghemat uang adalah untuk tabungan mereka. Hal ini juga bersinggungan dengan tingkat bunga yang tinggi maka akan menambah biaya yang harus dikeluarkan oleh perusahaan dan akhirnya mengakibatkan penurunan kegiatan produksi dalam negeri. Disamping itu, BI 7DRR merupakan kebijakan yang dikeluarkan oleh pemerintah yang menyesuaikan keadaan ekonomi yang terjadi di Indonesia sehingga kemudian dari penurunan produksi ini akan berpengaruh kepada zakat yang harus dikeluarkan oleh perusahaan sehingga zakat yang terkumpul juga berkurang.

\section{METODOLOGI}

Penelitian ini menggunakan pendekatan kuantitatif yang mana data penelitian berbentuk angka dan analisis menggunakan statistik (Sugiyono, 2018). Metode yang digunakan adalah metode deskriptif-kausalitas yang digunakan untuk mencari penjelasan tentang hubungan sebab akibat antara konsep dan juga variabel.

Sumber data yang digunakan yaitu data inflasi, kurs dollar, BI 7DRR dan Indeks Produksi Industri (IPI). Data tersebut diambil dari laman resmi Bank Indonesia (BI), Kementrian Perdagangan (Kemendag) yaitu data bulanan time series dari bulan Januari 2015 sampai Desember 2018 dengan teknik analisis data VAR (Vector Autoregression) apabila data tidak stasioner pada level tetapi terkointegrasi atau dengan Vector Error Correction Model (VECM) jika data yang digunakan adalah data yang stationer dan ada kointegrasi. Analisis yang digunakan oleh penulis adalah analisis regresi berganda dengan menggunakan software Eviews 9 (Rosadi, 2012).

Langkah pertama adalah menguji data dengan stationeritas yaitu menggunakan uji akar unit (unit root test) dan tes kointegrasi Johansen. Kemudian mengambil langkah untuk mengestimasi dan menentukan jeda optimal (optimum lag). Selanjutnya, model tersebut diuji untuk efek melalui tes kausalitas Engel-Granger dan tes VAR atau VECM. Pada uji analisis akhir adalah Impulse Respons dan Variance Decomposition.

Penelitian ini memiliki tiga variabel independen yaitu nilai kurs dollar (D), tingkat suku bunga (I), IPI (P) dan tingkat BI 7DRR (B) sedangkan variabel dependennya adalah 
jumlah penghimpunan zakat $(Z)$ yang datanya diambil dari laman resmi Badan Nasional Zakat (Baznas) pusat dari laporan keuangan bulanan.

\section{HASIL PENELITIAN DAN PEMBAHASAN}

Pembahasan dalam hasil penelitian ini dimulai dari langkah pertama dalam menguji data yaitu menguji stationeritas data penelitian. Uji stationeritas (Unit Root Test) menggunakan pendekatan Augmented Dickey Fuller (ADF). Jika nilai probabilitasnya atau P-value kurang dari 0.05 maka data yang didapatkan telah stationer ditingkat nyata 5\% (pada level).

Tabel 2. Tes Stationeritas pada Level

\begin{tabular}{c|c|c|l}
\hline Variabel & ADF Statistics & P-Value & \multicolumn{1}{|c}{ Information } \\
\hline Zakat & -2.748079 & 0.0739 & Non Stationary \\
\hline Inflasi & -1.501177 & 0.5241 & Non Stationary \\
\hline BI 7DRR & -1.496171 & 0.5266 & Non Stationary \\
\hline Kurs Dollar & -1.946396 & 0.3089 & Non Stationary \\
\hline IPI & -0.892558 & 0.7814 & Non Stationary
\end{tabular}

Sumber: (data diaolah, 2019)

Berdasarkan data pada tabel di atas menunjukkan bahwa data penelitian tidak stationer di tingkat level sehingga perlu diuji pada uji first difference, dengan hasil sebagai berikut:

Tabel 3. Tes Stationeritas pada First Difference

\begin{tabular}{c|c|c|c}
\hline Variabel & ADF Statistics & P-Value & Information \\
\hline Zakat & -6.395805 & 0.0000 & Stationary \\
\hline Inflasi & -4.842750 & 0.0003 & Stationary \\
\hline BI 7DRR & -4.782504 & 0.0003 & Stationary \\
\hline Kurs Dollar & -8.294513 & 0.0000 & Stationary \\
\hline IPI & -8.832318 & 0.0000 & Stationary
\end{tabular}

Sumber: (data diolah, 2019)

Berdasarkan hasil dari tabel 3 dapat disimpulkan bahwa data penelitian berada pada titik stationer di first difference. Kemudian, langkah berikutnya adalah menentukan lag optimal yang mana panjang lag ditentukan oleh hasil dari Likelihood Ratio (LR), Final Prediction Error (FPE), Akaike Information Criterion (AIC), Schwarz Information Criterion (SC), dan Hanan-Quin Criterion (HQ) yang ditandai dengan tanda bintang (*). Lag dengan tanda * terbanyak adalah lag yang terpilih untuk estimasi pada tahap berikutnya. 
Tabel 4. Tes Lag Stationaritas Optimal

\begin{tabular}{c|c|l|l|l|l|l}
\hline Lag & \multicolumn{1}{c|}{ Logl } & \multicolumn{1}{c|}{ LR } & \multicolumn{1}{c}{ FPE } & \multicolumn{1}{c}{ AIC } & \multicolumn{1}{c}{ SC } & \multicolumn{1}{c}{ HQ } \\
\hline 0 & -617.0326 & NA & 1309116. & 28.7421 & 28.47696 & 28.34940 \\
\hline 1 & -469.0258 & 255.6481 & $4925.365^{*}$ & 22.68299 & $23.89948^{*}$ & $23.13413^{*}$ \\
\hline 2 & -448.4880 & 30.80673 & 6314.225 & 22.88582 & 25.11605 & 23.71290 \\
\hline 3 & -418.8506 & $37.72033^{*}$ & 5767.406 & $22.67503^{*}$ & 25.91901 & 23.87805 \\
\hline
\end{tabular}

Sumber: (data diolah, 2019)

Hasil dari tabel 4 di atas dapat dilihat bahwa nilai yang memiliki bintang adalah nilai terkecil dalam kriteria sehingga lag pada nilai tersebut adalah lag optimal. Pada hasil ini, mayoritas hasil uji yang berbintang ada di lag 1. Oleh karena itu, dalam penelitin ini lag 1 adalah yang paling optimal. Kemudian analisis kointegrasi karena uji ini penting untuk mengetahui keseimbangan jangka panjang antara variabel yang diamati. Suatu persamaan dikatakan memiliki koeintegrasi jika nilai trace statistic atau max-eigen satust lebih besar dari pada critical value-nya.

Analisi selanjutnya adalah uji kointegrasi yang pada dasarnya bertujuan untuk melihat keseimbangan jangka panjang di antara variabel-variabel yang diobservasi dan dianalisis.

Tabel 5. Tes Kointegrasi

\begin{tabular}{c|c|c}
\hline Hypothesized No. of CE (s) & Trace Statistic & 0.05 Critical Value \\
\hline None $^{*}$ & 79.37811 & 69.81889 \\
\hline At most 1* & 48.80154 & 47.85613 \\
\hline At most 2 & 23.38507 & 29.79707 \\
\hline At most 3 & 6.836688 & 15.49471 \\
\hline At most 4 & 2.486961 & 3.841466 \\
\hline
\end{tabular}

Sumber: (data diolah, 2019)

Berdasarkan tabel 5 dapat dilihat bahwa hasil uji kointegrasi Johansen menunjukkan adanya kointegrasi karena trace value dan max-eigen statictics lebih besar dari nilai kritis 5\%. Hal ini menunjukkan bahwa pergerakan variabel antara zakat, inflasi, BI 7DRR, kurs dollar dan IPI memiliki hubungan keseimbangan dan gerakan yang sama pada jangka panjang dimana setiap periode jangka pendek, semua variabel cenderung menyesuaikan satu sama lain untuk mencapai keseimbangan jangka panjangnya. Setelah menguji optimal lag dan kointegrasi maka selanjutnya dilakukan pengujian kausalitas dengan menggunakan Engel-Grager untuk melihat pengaruh timbal balik antara variabel penghimpunan zakat, inflasi, BI 7DRR, kurs dollar dan jug a indeks produksi industri. Persamaan model dapat didefinisikan sebagai berikut: 


$$
\mathrm{Z}=\alpha+\beta_{1} \mathrm{D}+\beta_{2} \mathrm{I}+\beta_{3} \mathrm{P}+\beta_{4} \mathrm{~B}+\ldots+\beta_{\mathrm{n}} \mathrm{X}_{\mathrm{n}}+\mathcal{E}
$$

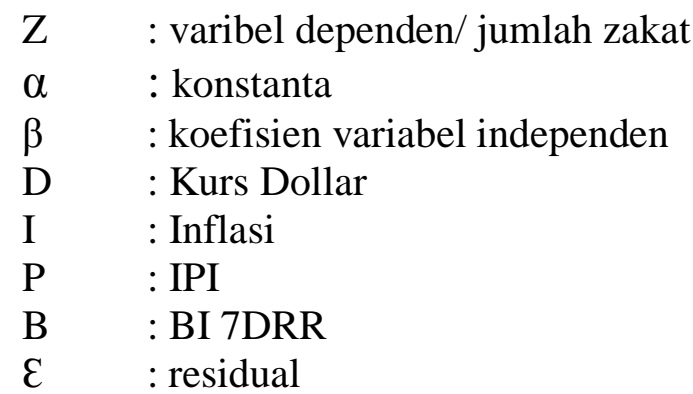

Hasil uji di atas perlu di uji dengan analisis selanjutnya untuk melihat adanya hubungan timbal balik dari hasil uji yang telah terkointegrasi sebelumnya dengan menggunakan uji Engel-Granger atau disebut uji Johansen.

Tabel 6. Tes Kausalitas Engel-Granger

\begin{tabular}{l|c|c}
\multicolumn{1}{c|}{ Hypothesis } & F Statistic & Prob. \\
\hline Kurs_Dollar does not Granger cause zakat & 4.53714 & 0.0389 \\
\hline Zakat does not Granger cause Kurs_Dollar & 1.43491 & 0.2375 \\
\hline IPI does not Granger cause Zakat & 5.11600 & 0.0288 \\
\hline Zakat does not Granger cause IPI & 4.99286 & 0.0307 \\
\hline Inflasi does not Granger cause Zakat & 2.15442 & 0.1494 \\
\hline Zakat does not Granger cause Inflasi & 0.20070 & 0.6564 \\
\hline BI_7-DRR does not Granger cause Zakat & 2.73148 & 0.1057 \\
\hline Zakat does not Granger cause BI_7-DRR & 4.15318 & 0.0477 \\
\hline
\end{tabular}

Sumber: (data diolah, 2019)

Berdasarkan tabel 6 di atas dapat disimpulkan bahwa hasil yang diperoleh menunjukkan pada level lima persen yaitu dimana ketika nilai probabilitas di bawah 0.05 menunjukkan bahwa setiap variabel tidak memiliki pengaruh timbal balik yang signifikan terhadap jumlah zakat. Namun ada beberapa variabel yang memiliki pengaruh timbal balik yaitu kurs dollar terhadap zakat dengan nilai probabilitas 0.0389 yaitu lebih kecil nilainya dari 0.05 IPI terhadap zakat dengan nilai probabilitas $0.0288<0.05$ begitu pula dengan zakat terhadap IPI dengan nilai 0.0307 serta pengaruh zakat terhadap BI 7DRR yang memiliki pengaruh timbal balik yang signifikan dengan nilai probabilitas 0.0477 .

Dengan terpilihnya model VECM untuk menganalisis data dalam penelitian ini digambarkan untuk melihat perilaku dinamis dari bentuk data waktu ekonomi dan keuangan dan untuk meramalkan pada perkiraan jangka pendek ataupun panjang. Penelitian ini menggunakan signifikansi dengan nilai kritis 5\% dimana nilai t-table nya adalah 1.68. Variabel yang dinyatakan memiliki pengaruh signifikan jika nilai mereka menolak H0 apabila $>1.68$ atau menerima $\mathrm{H} 1$ saat itulah nilai t-statistik $<1.68$.

Tabel berikut ini menunjukkan tentang tes hasil VECM dalam jangka pendek dan jangka panjang. 
Tabel 7. Tes hasil VECM

\begin{tabular}{|c|c|c|c|}
\hline \multicolumn{4}{|c|}{ Long Term } \\
\hline Variable & Coefficient & T-Statistic & Description \\
\hline Zakat & \multicolumn{3}{|l|}{1.000000} \\
\hline Kurs_Dollar & -0.001608 & {$[-5.80889]$} & Significant \\
\hline IPI & 0.058414 & {$[2.05615]$} & Significant \\
\hline Inflasi & -0.229408 & {$[-2.33407]$} & Significant \\
\hline BI_7DRR & 0.681806 & [ 4.18407] & Significant \\
\hline \multicolumn{4}{|c|}{ Short Term } \\
\hline D (Zakat(-1)) & -0.126819 & {$[-0.85936]$} & Not Significant \\
\hline D (Kurs_Dollar(-1)) & -0.000517 & {$[-1.68971]$} & Significant \\
\hline $\mathrm{D}(\mathrm{IPI}(-1))$ & 0.000342 & {$[0.02349]$} & Not Significant \\
\hline D (Inflasi $(-1))$ & 0.291725 & [ 1.73101$]$ & Significant \\
\hline D (BI_7DRR(-1)) & 0.477283 & [ 1.53491$]$ & Not Significant \\
\hline $\mathrm{C}$ & 0.106244 & [ 1.39877$]$ & Not Significant \\
\hline R-Squared & 0.408378 & & \\
\hline Adj R-Squared & 0.314964 & & \\
\hline
\end{tabular}

Sumber: (data diolah, 2019)

Berdasarkan hasil dari tabel 7 di atas menjelaskan bahwa dalam jangka panjang variabel kurs dollar, inflasi dan IPI memiliki pengaruh yang signifikan terhadap jumlah zakat yang terhimpun. Sementara itu, IPI memiliki pengaruh positif dan berpengaruh signifikan terhadap jumlah zakat. Sedangkan dalam jangka pendek, efek IPI dan BI 7DRR terhadap zakat tidak signifikan. Sedangkan pada variabel inflasi dan kurs dollar memiliki pengaruh yang signifikan terhadap zakat karena nilai t-statisticnya yaitu $1.73101>1.68$ lebih besar dari t tabel sehingga memiliki pengaruh yang positif dan signifikan terhadap jumlah zakat. Nilai koefisien R-squared dalam model adalah 0.408378 dan nilai adj. Rsquared ada di titik 0.314964 yang mana berarti jumlah variabel zakat pada periode 20152018 dapat dijelaskan oleh variabel kurs dollar, IPI, inflasi dan BI 7DRR sebesar $41 \%$ atau $31 \%$. Sedangkan 59\% dan 69\% dijelaskan oleh faktor atau variabel diluar model penelitian ini. Hasil uji dari VECM ini dapat disajikan dalam model persamaan yang terbentuk nilai koefisien pada masing-masing variabel dalam jangka pendek dan jangka panjang.

Tabel ini menjelaskan model persamaan penelitian tentang pengaruh kurs dollar, IPI, inflasi dan BI 7-DRR pada penghimpunan zakat di Baznas Indonesia yang mana dalam jangka panjang:

D_Zakat $=-0.001608$ Kurs_Dollar +0.058414 IPI -0.229408 Inflasi+ 0.681806 BI_7DRR

Kemudian model persamaan penelitian dalam jangka pendek adalah sebagai berikut:

D_Zakat $=-0.126819$ Zakat $(-1)-0.000517$ Kurs_Dollar $(-1)+0.000342$ IPI $(-1)+$ 0.291725 Inflasi $(-1)+0.477283$ BI_7DRR $(-1)$ 
Berdasarkan hasil dari tabel 7 yaitu analisis VECM, pengaruh kurs dollar memiliki pengaruh negatif yang signifikan terhadap zakat dengan koefisien nilai -0.001608 yang menunjukkan bahwa setiap kenaikan tingkat kurs dollar satu persen akan berdampak pada penurunan penghimpunan zakat sebesar 0.001608 poin. Hal ini menyebutkan bahwasanya setiap peningkatan kurs dollar terhadap rupiah maka dapat menurunkan daya beli masyarakat karena harga barang semakin naik. Beda halnya dengan masyarakat yang mendapatakan penghasilan dalam bentuk dollar sehingga zakat yang dikeluarkan juga semakin banyak meskipun masih jarang yang mendapatkan pendapatan dalam bentuk dollar, hasil ini sesuai dengan penelitian dari (Azis dan Widiastuti, 2017).

Begitu pula dengan variabel lainnya, seperti IPI pada kausalitas jangka panjang memiliki pengaruh yang signifikan dan berpengaruh positif sedangkan pada kausalitas jangka pendek IPI memiliki pengaruh yang tidak signifikan. Hasil ini dapat disimpulkan bahwa setiap peningkatan level IPI pada satu titik akan berdampak pada penurunan zakat sebesar 0.058414 poin. IPI digunakan untuk merepresentasikan pendapatan nasional atau PDB untuk menggantikan data bulanan dari tidak adanya data PDB setiap bulan, ditambah lagi bahwa sektor industri merupakan sektor terbesar di Indonesia yang dapat diandalkan untuk pertumbuhan ekonomi. Hasil dari VECM di atas sesuai dengan penelitian (Saadillah, 2019) apabila PDB meningkat maka kemampuan membayar zakat juga akan meningkat sehingga otomatis jumlah zakat yang terkumpul juga bertambah.

Pengaruh positif yang dihasilkan oleh inflasi terhadap zakat tidak sesuai dengan teori dampak inflasi yang menjelaskan bahwa kenaikan inflasi akan meningkatkan harga barang sehingga nilai mata uang akan menurun dan berimbas pada pengurangan daya beli masyarakat dan konsumsinya pada teori (Mankiw, 2007) dan juga dari penelitian dari (Saadillah, 2019). Dari hasil inflasi yang signifikan terhadap zakat secara temporary sesuai dengan hasil jangka pendek dan panjang yang nilainya positif dan signifikan dimana berpengaruh terhadap pendapatan dan pengeluaran masyarakat miskin sehingga akan meningkatkan kemiskinan dan jumlah yang menerima zakat akan semakin meningkat. Hal ini karena inflasi juga berdampak kepada pendapatan, output, kenaikan suku bunga yang menggambarkan kenaikan harga secara umum sehingga juga berdampak kepada tingkat kesejahteraan rakyat.

Sedangkan pada hasil penelitian menunjukkan bahwa BI 7DRR dalam kausalitas jangka panjang berpengaruh signifikan sedangkan pada kausalitas jangka pendek BI 7DRR tidak berpengaruh signifikan. Hasil koefisien yang diperoleh adalah 0.681806 yang mana ini menunjukkan bahwa setiap kenaikan BI 7DRR sebesar satu persen akan berdampak pada penurunan jumlah zakat yang diterima oleh Baznas sebesar 0.681806 poin. Hasil ini menyimpulkan bahwa pada kausalitas jangka panjang perubahan BI 7DRR mempengaruhi jumlah penerimaan zakat di Baznas sehingga sedangkan jika suku bunga naik, masyarakat tidak banyak berinvestasi karena bunga pinjaman yang terlalu tinggi sehingga jumlah investasi menurun sehingga berimbas pada menurunnya penghasilan orang juga (Sinay, 2014), sedangkan pada kausalitas jangka pendek tidak mempengaruhi zakat secara signifikan.

Berikut ini adalah pembahasan tentang peramalan dan analisis struktur peramalan dari model VECM dengan pembahasan awal tentang analisis struktural yang mencakup analisis Impulse-Response dan Variance Decomposition. 
Gambar 2. Analisis Impulse-Response

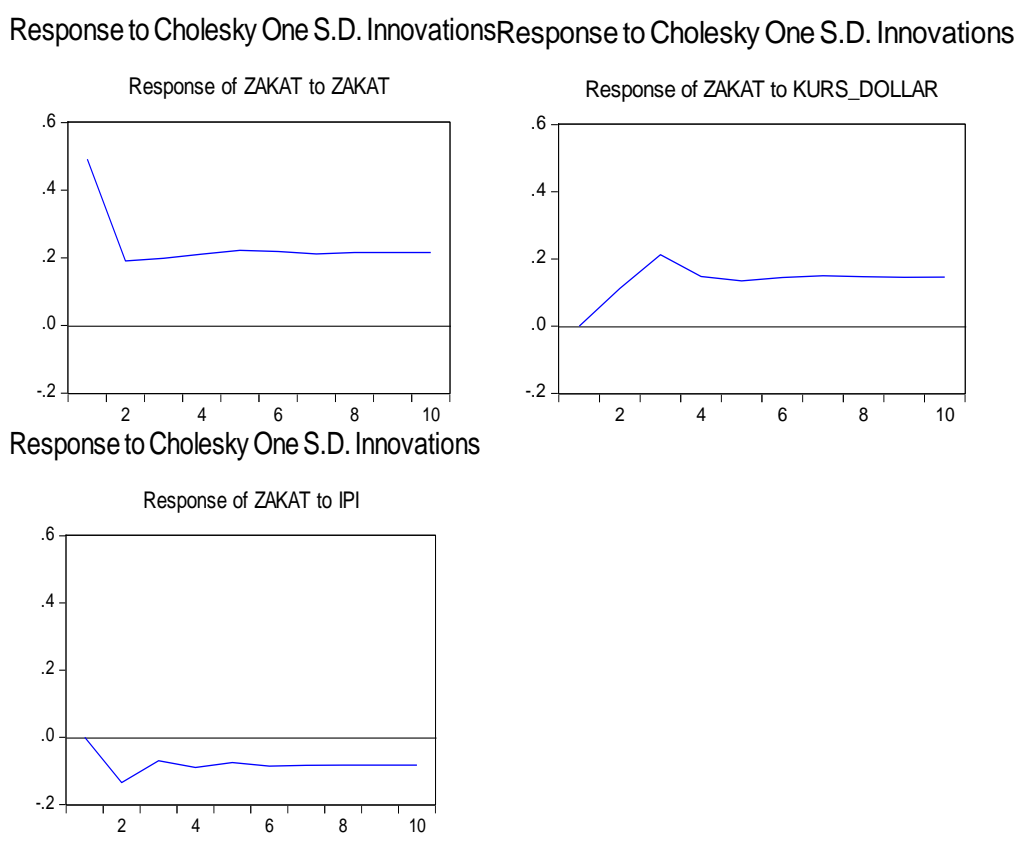

Response to Cholesky One S.D. InnovationsResponse to Cholesky One S.D. Innovations
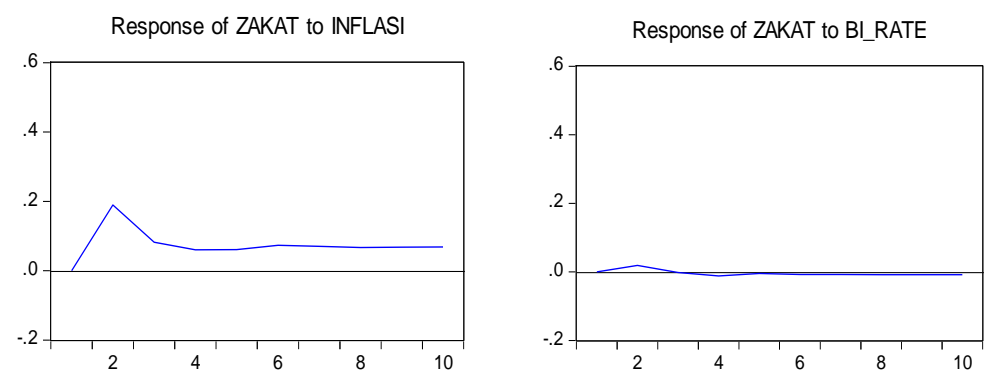

Analisis impulse-response dapat menggunakan fungsi impulse-response (IRF). Berdasarkan gambar di atas ada 5-plot IRF untuk 10 periode ke depan yang mana menjelaskan secara visual tentang tanggapan (response) suatu variabel yang timbul karena adanya shock (impulse) sebesar 1 standar deviasi yaitu baik dari dirinya sendiri ataupun dari variabel lainnya.

Berdasarkan gambar 2 bahwa analisis IRF dari tingkat zakat untuk 10 periode ke depan sebagai berikut: (1) Respon tingkat zakat terhadap guncangan dari dirinya sendiri pada periode 1 yaitu 0.491655 yang mana berbeda pada saat periode 2 hingga periode 10 mengalami penurunan. Hal ini berarti bahwa setelah periode 2 reaksi tingkat zakat terhadap guncangan dari dirinya sendiri cenderung menjadi lemah. (2) Respon tingkat zakat terhadap guncangan dari kurs dollar pada periode 1 ke periode 3 meningkat sekitar 0.100512 kemudian pada periode 4 sampai dengan periode 10 mengalami fluktuasi yang naik turun namun dengan jarak yang tidak terlalu banyak, berarti bahwa reaksi yang diberikan oleh tingkat zakat terhadap guncangan kurs dollar cenderung naik turun. (3) Respon yang didapatkan zakat terhadap IPI cenderung bernilai negatif. Hal ini dimaksudkan bahwa jika terjadi guncangan sebesar 1 standar deviasi dari nilai IPI maka tingkat zakat akan bereaksi 
negatif terhadap IPI. (4) Respon yang diterima dari tingkat zakat terhadap inflasi pada periode 1 ke periode 2 mengalami peningkatan 0.189445 namun pada periode 3 hingga periode 10 cenderung mengalami naik turun meskipun jarang naik atau turunnya tidak terlalu jauh dari satu periode ke periode lainnya. (5) Respon dari tingkat zakat terhadap BI 7DRR dari periode satu ke periode 2 naik sekitar 0.018852 namun pada periode 3 sampai pada periode 10 cenderung mengalami penurunan dan bernilai negatif. Sama halnya dengan IPI bahwa setiap terjadi guncangan sebesar 1 standar deviasi dari nilai BI 7DRR maka tingkat zakat akan bereaksi negatif terhadap BI 7DRR.

Berikut merupakan analisis Variance Decomposition (dekomposisi variansi) yang biasa disebut sebagai Forecast Error Decomposition Variance (FEDV). Hasil analisis ini ditunjukkan melalui tabel 8 untuk 10 periode dari variabel zakat.

Tabel 8. Dekomposisi Variansi: Variabel ZAKAT

\begin{tabular}{c|c|c|c|c|c|c}
\hline \multicolumn{7}{c}{ Variance Decomposition of ZAKAT } \\
\hline Period & S.E. & Zakat & Kurs_Dollar & IPI & Inflasi & BI_7DRR \\
\hline 1 & 0.457192 & 100.0000 & 0.000000 & 0.000000 & 0.000000 & 0.000000 \\
\hline 2 & 0.537615 & 78.36061 & 6.263251 & 1.964883 & 11.22106 & 2.190188 \\
\hline 3 & 0.579999 & 69.73064 & 15.68369 & 1.746165 & 10.91133 & 1.928173 \\
\hline 4 & 0.611063 & 66.74944 & 19.29067 & 1.833967 & 10.01424 & 2.111697 \\
\hline 5 & 0.634846 & 65.76608 & 20.84820 & 1.792567 & 9.472416 & 2.120739 \\
\hline 6 & 0.661455 & 64.24807 & 22.77903 & 1.788238 & 9.101497 & 2.083159 \\
\hline 7 & 0.685439 & 62.63379 & 24.72444 & 1.771586 & 8.804410 & 2.065779 \\
\hline 8 & 0.708765 & 61.37371 & 26.31918 & 1.750533 & 8.468529 & 2.088055 \\
\hline 9 & 0.731139 & 60.33584 & 27.62901 & 1.743529 & 8.184902 & 2.106719 \\
\hline 10 & 0.752899 & 59.40222 & 28.80703 & 1.732899 & 7.941373 & 2.116481 \\
\hline
\end{tabular}

Sumber: (data diolah, 2019)

Hasil dari tabel 8 merupakan hasil analisis FEDV untuk tingkat zakat dari guncangan yang diberikan oleh masing-masing variabel termasuk dirinya sendiri. dalam jangka pendek yaitu pada periode 3, guncangan zakat terhadap dirinya sendiri mengakibatkan $69.74 \%$ fluktuasi dalam tingkat zakat dan guncangan terhadap kurs dollar mengakibatkan $15.69 \%$ fluktuasi dalam tingkat zakat, kemudian IPI mengakibatkan $1.74 \%$ terhadap zakat, guncangan inflasi juga mengakibatkan $10.91 \%$ dan BI 7DRR mengalami guncangan sebesar $1.92 \%$ fluktuasi dalam tingkat zakat. Pada tingkatan lainnya, dalam jangka panjang yaitu pada periode 10 menyimpulkan bahwasanya guncangan terhadap dirinya sendiri mengakibatkan semakin lemah fluktuasi dalam tingkat zakat sedangkan pada kurs dollar mengakibatkan fluktuasi semakin meningkat dalam tingkat zakat. Sedangkan pada variabel IPI dan inflasi cenderung mengalami penurunan setiap periodenya. Berbeda halnya dengan BI 7DRR yang mengalami fluktuasi naik turun di setiap periodenya sehingga secara umum dinyatakan bahwa fluktuasi yang diakibatkan oleh guncangan nilai IPI dan BI 7DRR dalam tingkat penghimpunan zakat sangat kecil dari dua variabel lainnya yaitu kurs dollar dan inflasi. 


\section{KESIMPULAN}

Berdasarkan spesifikasi model dari analisis lag optimum dan pemeriksaan model yaitu uji serial korelasi residual maka model yang terbaik untuk data pengaruh inflasi, IPI, BI 7DRR dan kurs dollar terhadap jumlah zakat adalah Vector Error Correction Model (VECM).

Hasil analisis kausalitas yang didapatkan adalah terdapat hubungan kausalitas jangka panjang dan pendek antara tingkat zakat sebagai variabel dependen dengan inflasi dan kurs dollar. Namun, tidak ada hubungan kausalitas jangka pendek antara BI 7DRR dan IPI terhadap jumlah zakat sedangkan untuk hubungan kausalitas jangka panjang, semua variabel independen memiliki hubungan yang signifikan terhadap variabel dependen yaitu zakat.

Pada analisis struktural dari VECM menyatakan bahwa respon dari masing-masing variabel terhadap memiliki guncangan yang berbeda-beda dimana guncangan zakat terhadap dirinya sendiri cenderung melemah dari periode 2 hingga periode 10. Guncangan inflasi dan kurs dollar terhadap zakat ini cenderung mengalami fluktuasi naik turun setiap periodenya. Sedangkan IPI dan BI 7DRR mengalami penurunan yang bernilai negatif di setiap periodenya terhadap zakat.

Secara umum bahwa untuk analisis selanjutnya bahwa dalam jangka panjang maupun jangka pendek, tingkat inflasi dan kurs dollar saling mempengaruhi zakat secara signifikan. Sementara BI DRR dan IPI memiliki pengaruh yang kurang signifikan terhadap jumlah zakat. Untuk menjaga dan memperkuat jumlah zakat yang terhimpun, perlu adanya stabilitasi tingkat inflasi dan nilai tukar terhadap dollar sehingga kesejahteraan masyarakat yang kurang mampu dapat terpenuhi.

\section{DAFTAR PUSTAKA}

Al Qur'an

Afendi, A. (2018). Pengaruh Variabel Makroekonomi Terhadap Jumlah Penerimaan Zakat di Badan Amil Zakat Nasional ( Baznas ) Pusat Tahun 2012 - 2016, Jurnal Muqtasid IAIN Salatiga 9(1). http://dx.doi.org/10.18326/muqtasid.v9i1. 54-69.

Ahmad, Z. M. (2011). Pengaruh Indikator Makroekonomi terhadap Besarnya Jumlah Zakat yang terkumpul di Lembaga Amil Zakat Dompet Dhuafa Republika tahun 1993-2009.

Ahmed, B. O., Johari, F., and Wahab, K. A. (2017). "Identifying the poor and the needy among the beneficiaries of zakat Need for a zakat-based poverty threshold in Nigeria". International Journal of Social Economics 446-458. https://doi.org/10.1108/IJSE-092015-0234.

Andriyanto, I. (2011). "Strategi Pengelolaan Zakat Dalam Pengentasan Kemiskinan". Jurnal Walisongo STAIN Kudus, 19, 25-46.

Anggara, M. S. (2017). "Pengaruh Variabel Makroekonomi Terhadap Peningkatan Penerimaan Pendapatan Asli Daerah Kota Pekanbaru". Jurnal Online Mahasiswa Fakultas Ekonomi Universitas Riau, Vol. 4 No., 898-913.

Azis, H. A., dan Widiastuti, T. (2017). Zakat dan Pemberdayaan (Edisi Pert). Surabaya: Airlangga University Press.

Chapra, U. (2018a). Islam dan Pembangunan Ekonomi (Indonesian). Solo: Aqwam Jembatan Ilmu. 
Chapra, U. (2018b). Sistem Moneter Islam (Indonesian). Depok: Gema Insani.

Cokrohadisumarto, M. (2019). "A study of Indonesian community's behaviour in paying zakat", Journal of Islamic Marketing (59). https://doi.org/10.1108/JIMA-10-20180208.

Fitriah Nurmu'minah, S., Asmara, A., dan Lubis, D. (2015). "Dampak Makroekonomi pada Penghimpunan ZIS Baznas Pusat". Iqtishodia Jurnal Ekonomi Islam Republika.

Huda, N. (2012). Keuangan Publik Islam (Pertama). Jakarta: Kencana.

Kasri, R.A. (2013). "Giving Behaviors In Indonesia: Motives And Marketing Implications For Islamic Charities", Journal of Islamic Marketing vol. 4 No. 3 pp.306-324. DOI 10.1108/JIMA-05-2011-0044.

Lidya, N. M., dan Maryati, T. (2015). "Analisis pengaruh inflasi, kurs, suku bunga dan bagi hasil terhadap deposito pada pt. bank syariah mandiri 2007-2012", (7), 735-745. Jurnal Trisakti Semnas Cendekiawan.

Mankiw. (2007). Macroeconomics (Sixth Edit). New York: Harvard University.

Obaidullah, M. (2016). "Revisiting Estimation Methods Of Business Zakat And Related Tax Incentive", Journal of Islamic Accounting and Business Research Vol. 7 No. 4 pp.349-364. DOI 10.1108/JIABR-10-2014-0035.

Omar, M. Bin. (2016). "Konsep Zakat Dan Peranannya Terhadap Masyarakat Sejagat" . Muzakarah Fiqh \& International Fiqh Conference, (November), 68-86.

Saadillah, R. (2019). "Impact of Inflation, Interest Rate, and Industrial Production Index ( IPI ) on the Amount of Zakat in Central Baznas Period", 2019, 1371-1385. The $2^{\text {nd }}$ International Conference on Islamic Economics, Business, and Philantrophy $2^{\text {nd }}$ ICIEBP. https://doi.org/10.18502/kss.v3i13.4291.

Saikh, S.A. (2015). "Welfare potential of zakat: an attempt to estimate economy wide zakat collection in Pakistan", The Pakistan Development Review, Vol. 54, No. 5 Desember 2-4 (winter 2015) pp. 1011-1027.

Sloane-White, P. (2019). Collecting, Resisting, and Paying Corporatized Zakat in Contemporary Malaysia. In Lemière S. (Ed.), Illusions of Democracy: Malaysian Politics and People (pp. 271-286). Amsterdam: Amsterdam University Press. doi:10.2307/j.ctvnjbgtv.19.

Rahmat, R. S., and Nurzaman, M. S. (2019). "Assesment of zakat distribution A case study on zakat community development", (1989). International Journal of Islamic and Middle Eastern Finance and Management Vol. 12 No. 5, 743-766. https://doi.org/10.1108/IMEFM-12-2018-0412.

Rio, B. (2016). Pengaruh Indikator Makroekonomi: Inflasi dan Nilai Tukar Rupiah Terhadap Jumlah Zakat Terkumpul di Lembaga Amil Zakat Dompet Dhuafa Periode 1997-2013, Jurnal Ekonomi Syariah Teori dan Terapan Vol. 3 No.7 Juli 2016, 584599.

Rosadi, D. (2012). Ekonometrika dan Analisis Runtun Waktu Terapan dengan Eviews. Yogyakarta: ANDI Yogyakarta.

Sinay, L. J. (2014). Pendekatan Vector Error Correction Model Untuk Analisis Hubungan Inflasi , Bi Rate Dan Kurs Dolar Amerika Serikat Vector Error Correction Model Approach to Analysis of the relationship of Inflation, BI Rate and US Dollar, Jurnal Barekeng Ilmu Matematika dan Terapan 8(2), 9-18.

Skintzi, G. (2018). "Analysis of the Industrial Sector based on Industrial Production and Turnover Indices" (Oct 2018). KEPE, Greek Economic Outlook 2012-2019, 
(November).

Sugiyono. (2018). Metode Penelitian Bisnis Pendekatan Kuantitatif, Kualitatif, Kombinasi, dan $R \& D$. Bandung: Alfabeta.

Sulistiana, I. (2017). Model Vector Auto Regression ( VAR ) and Vector Error Correction Model ( VECM ) Approach for Inflation Relations Analysis , Gross Regional Domestic Product ( GDP ), World Tin Price , Bi Rate and Rupiah Exchange Rate, IJBE: Integrated Journal of Business and Economics. 17-32.

www.bi.go.id

www.bps.go.id

www.kemendag.go.id

www.baznas.go.id 